\title{
Ostracoda (Myodocopina) of Tutuila, American Samoa ${ }^{1}$
}

\author{
Louis S. Kornicker and Elizabeth Harrison-Nelson ${ }^{2}$
}

\begin{abstract}
Three species (two new) of myodocopid Ostracoda are reported from Tutuila, American Samoa: Paravargula trifax Kornicker, 1991; Cypridina mellentini Kornicker \& Harrison-Nelson, n. sp.; and Asteropterygion samoa Kornicker \& Harrison-Nelson, n. sp. Only C. mellentini was abundant. The genus Asteropterygion is reported for the first time from a southwestern central Pacific island. Paravargula trifax had been reported previously from Enewetak.
\end{abstract}

SAMOA IS A GROUP of islands in the southwestern central Pacific Ocean that has been divided into American Samoa for islands east of $171^{\circ} \mathrm{W}$ and Samoa for islands west of that longitude. Tutuila, the chief island of American Samoa, is $40.25 \mathrm{~km}$ (about 25 miles) long and 3.22 to $9.66 \mathrm{~km}$ (2 to 6 miles) wide (Figure 1). Pago Pago Harbor is a large bay on the eastern side of the island; it is one of the best harbors in the South Pacific. Fagatele Bay is a small bay on the southwestern edge of the island. In this study we describe myodocopid ostracods collected at three stations in Pago Pago Harbor and one station in Fagatele Bay.

Poulsen $(1962,1965)$ reported the following Myodocopina from Apia Harbor, Western Samoa: Codonocera polygonia Müller, 1906, Cypridina sinuosa (Müller, 1906), C. inermis (Müller, 1906), Cypridinodes asymmetrica (Müller, 1906), Melavargula nana Poulsen, 1962, and Synasterope quatrisetosa Poulsen, 1965. None of those species was in the collection reported here from Pago Pago and Fagatele Bay, which contained only three species. Two of the species (Asteropterygion samoa Kornicker \& Harrison-Nelson, n. sp., and Paravargula trifax Kornicker, 1991) were represented by only a single specimen. Spe-

${ }^{1}$ Manuscript accepted 1 July 2005.

${ }^{2}$ Department of Invertebrate Zoology, National Museum of Natural History, Smithsonian Institution, Washington, D.C. 20560-0163 (e-mail: kornickl@si.edu, nelsone@si.edu).

Pacific Science (2006), vol. 60, no. 2:243-259

(C) 2006 by University of Hawai'i Press

All rights reserved cies of those two genera had not previously been reported from Samoa. Adult females of the third species, Cypridina mellentini Kornicker \& Harrison-Nelson, n. sp., were fairly abundant, but adult males were not collected. Station data and species in each sample are presented in the Appendix.

\section{MATERIALS AND METHODS}

Sampling methods used at the stations are described in Coles et al. (2003). Ostracodes were retained with other macroinvertebrates from washings of coral rubble and macroalgae passed through a $0.5-\mathrm{mm}$ mesh screen, preserved in $70 \%$ ethanol, and then sorted from the samples in the laboratory at Bernice P. Bishop Museum in Honolulu (in lit., S. L. Coles, 2005).

\section{TAXONOMIC TREATMENT}

\section{Disposition of Specimens}

The holotypes and most paratypes of the two new species, and the single specimen of $P$. trifax have been deposited in the Bernice P. Bishop Museum and have been assigned врвм-S numbers. A paratype of $C$. mellentini has been deposited at the National Museum of Natural History, Smithsonian Institution, and has been assigned a USNM catalog number.

Order Myodocopida Sars, 1866

Suborder Myodocopina Sars, 1866

Family Cypridinidae Baird, 1850

composition: This family includes two subfamilies: Cypridininae Baird, 1850, and 


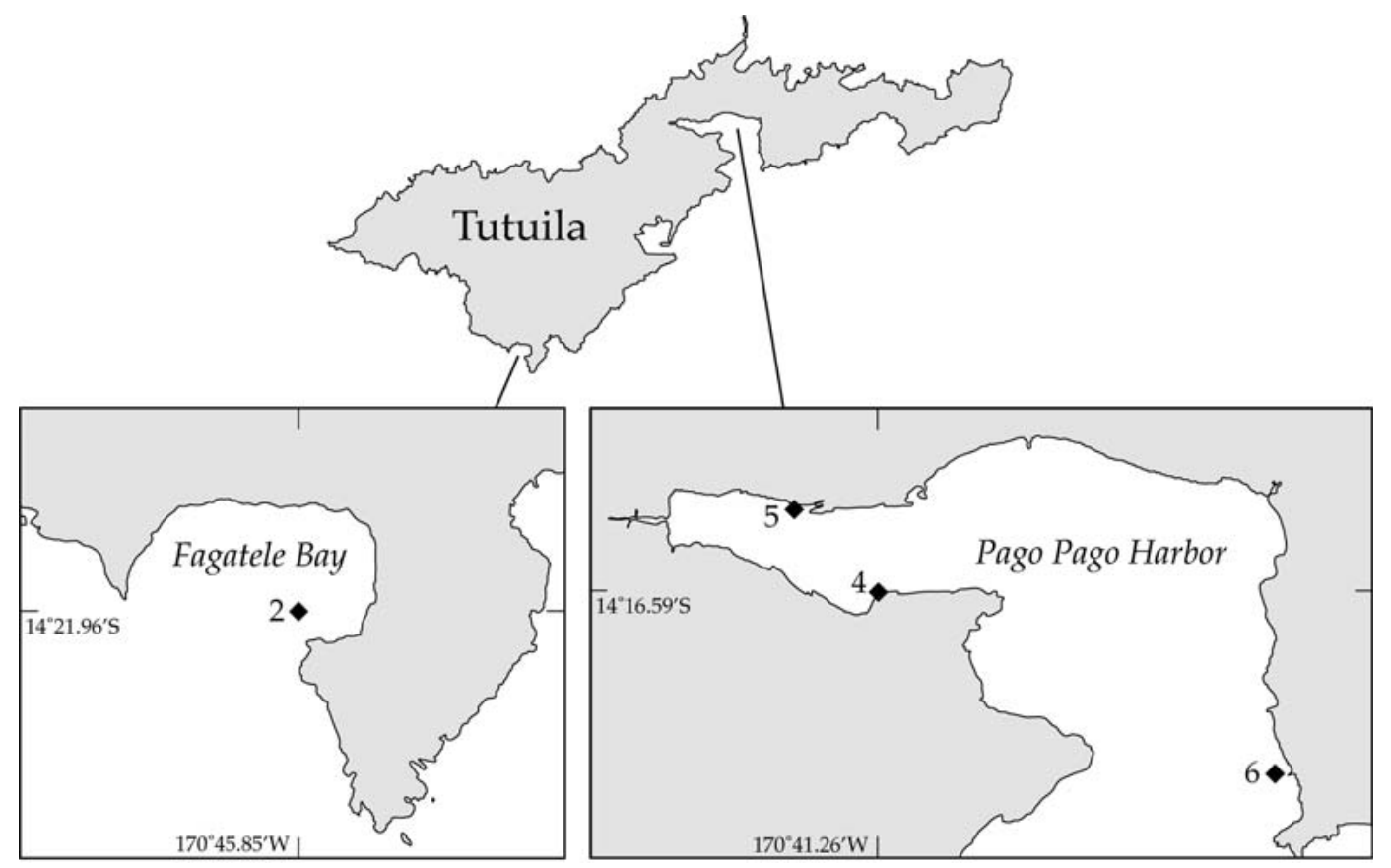

Figure 1. Map of the study area showing location of stations. (Map adapted from figure supplied by S. L. Coles.)

Azygocypridininae Kornicker, 1970. Only the former is in the collection reported here.

\section{Subfamily Cypridininae Baird, 1850}

composition: This subfamily includes two tribes, Cypridinini Baird, 1850, and Gigantocypridinini Hartmann \& Puri, 1974. Only the former is in the collection reported here.

Genus Paravargula Cohen \& Kornicker, 1975

Paravargula Poulsen, 1962:202 [nomen nudem].

Paravargula Cohen \& Kornicker, 1975:23 [designated type species].

TyPe SPECIES: Paravargula ensifera Poulsen, 1962:209, by subsequent designation (Cohen and Kornicker 1975:23).

COMPOSITION AND Distribution: This genus includes six species from the Philip- pines, Singapore, Kei Islands, East Indian region, South Africa, Taiwan, and American Samoa.

Paravargula trifax Kornicker, 1991 Figure $2 A-E$

Paravargula sp. Kornicker, 1987a:217.

Paravargula trifax Kornicker, 1991:5, figs. $2-4$.

HOLOTYPE: USNM 158322, adult female on slide and in alcohol.

TYPE LOCALITY: Enewetak Lagoon (night plankton trap, coral reef substrate).

MATERIAL EXAMINED: BPBM-S 12255, 1 instar III, sex undetermined, from Station 4, Main Dock, Pago Pago Harbor, Tutuila, American Samoa, 15 October 2002.

distribution: Enewetak Atoll, American Samoa.

SUPPLEMENTARY DESCRIPTION OF INstar iII (sex Undetermined): Carapace 

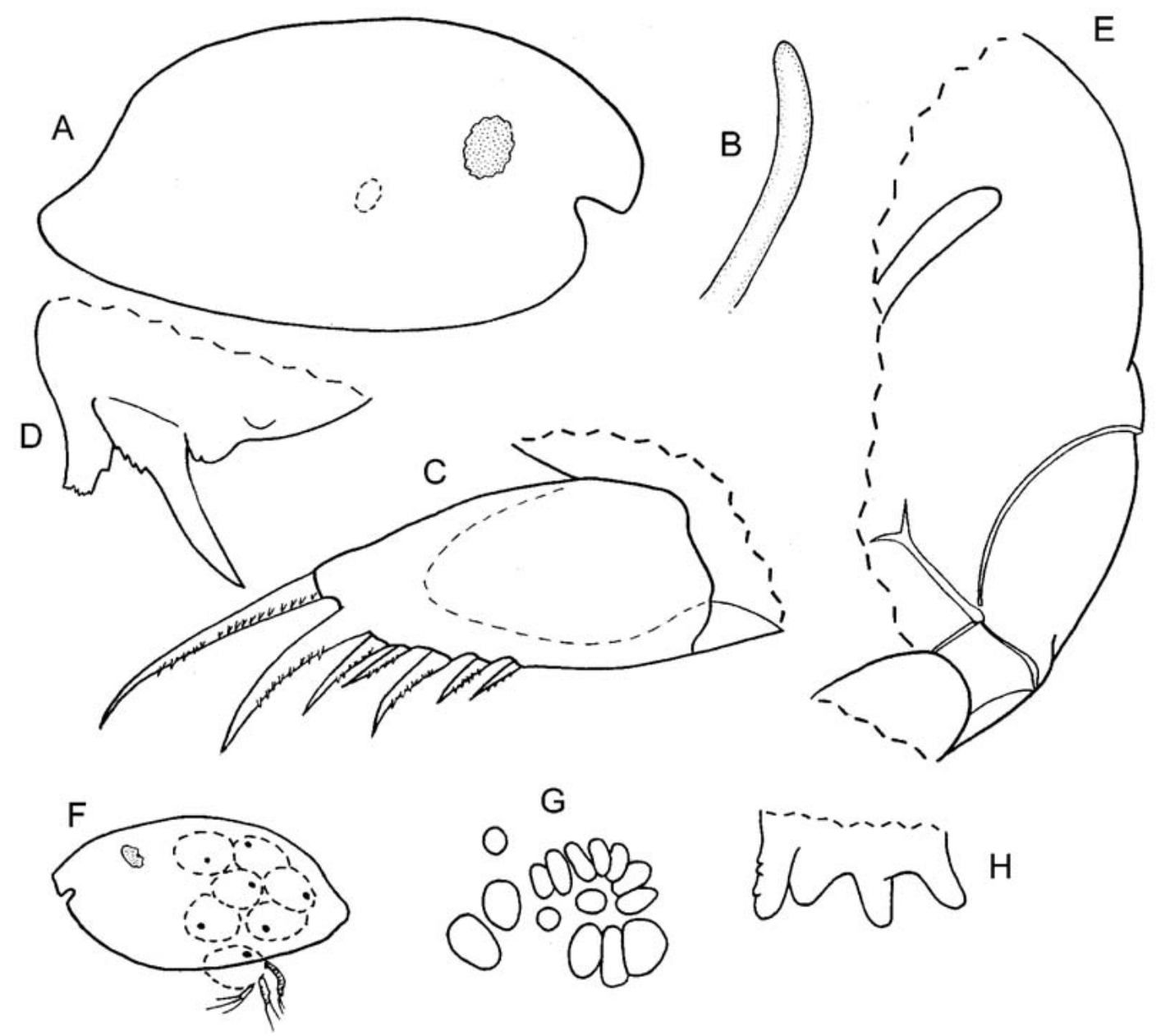

Figure 2. Paravargula trifax Kornicker, 1991, instar III, sex unknown, врвм-S 12255, $A-E$ : $A$, complete specimen from right side showing right lateral eye (stippled) and outline of central adductor muscles (dashed), length $1.35 \mathrm{~mm}$; $B$, right 7th limb; $C$, left furcal lamella; $D$, upper lip from left side, anterior to left; $E$, posterior of body from left side showing distal end of left 7th limb, Y-sclerite, and girdle. Cypridina mellentini, n. sp., F, ovigerous female, paratype, врвм-S 12264, complete specimen from left side showing left lateral eye, 6 eggs in marsupium (with lateral eyes), and 1 larva protruding from ventral edge of carapace. врвм-S 12259, adult female without eggs, paratype: $G$, central adductor muscles of left valve, outside view; $H$, upper lip from right side as seen through right valve, anterior to right.

with deep incisur and projecting caudal process (Figure $2 A$ ). Posterior edge of anterior ridge forming pocket of caudal process of each valve with spines.

Carapace size (length, height in $\mathrm{mm}$ ): врвм-S 12255, 1.13, 0.56 .

Sixth limb: With numerous bristles.

Seventh limb (Figure 2B,E): Elongate, bare.
Furca (Figure 2C): Each lamella with 7 claws. Claw 2 fused to lamella; claw 5 about same width and length as claw 3; claw 4 smaller.

Upper lip (Figure 2D): Thin projecting, unpaired processes anterior to paired long, slender tusks followed by 2 small paired processes. 
Genus Cypridina Milne-Edwards, 1840

Cypridina Milne-Edwards, 1840:409; Poulsen, 1962:255; Kornicker, 1987b:173; 1991:27; 1992:11.

Cypridina (Pyrocypris) Müller, 1890:230.

Eupathistoma Brady, 1898:437.

Pyrocypris Müller, 1890:213; 1906:16; 1912:16. Cypridina (Cypridina) Skogsberg, 1920:313.

TyPe species: Cypridina renaudii MilneEdwards, 1840:409, by monotypy.

COMPOSITION AND DISTRIBUTION: Kornicker (1991:27-29) recognized 21 species as Cypridina sensu Poulsen (1962:255). Kornicker (1992:11-33) described two additional species from the Mozambique Channel, Indian Ocean. One new species is described herein from American Samoa. Species have been collected in the Indian and Pacific Oceans between latitudes of about $35^{\circ} \mathrm{N}$ and $30^{\circ} \mathrm{S}$, planktonic and demersal (Kornicker 1991:28).

Cypridina mellentini Kornicker \& HarrisonNelson, n. sp.

Figures $2 F-H, 3,4,5$

ETymology: The species is named in honor of Erik Mellentin Poulsen, noted student of Ostracoda and other crustaceans.

HOLOTYPE: вРвM-S 12258, ovigerous female on slide and in alcohol.

TyPe locality: Station 6, Onososopo, Pago Pago Harbor, Tutuila, American Samoa, 17 October 2002.

paratypes: Pago Pago Harbor: Station 4, Main Dock, врвм-S 12256, ovigerous female on slide and in alcohol. Station 5, Dry Dock, врвм-S 12257, adult female in alcohol. Station 6, Onososopo, врвм-S 12259, adult female in alcohol; UsNm 1075533, adult female in alcohol; врвм-S 12261, A-1 male in alcohol; врвм-S 12262, 3 ovigerous females in alcohol; врвм-S 12263, 5 ovigerous females, 2 adult females, all in alcohol; врвм-S 12264,1 adult female with well-developed eggs with eyes in marsupium and 2 embryos with appendages or first instars projecting from ventral edge of carapace. distribution: Pago Pago Harbor, Tutuila, American Samoa: Station 4, Main Dock, 15 October 2002; Station 5, Dry Dock, 15 October 2002; Station 6, Onososopo, 17 October 2002.

DESCRIPTION OF ADULT FEMALE (Figures $2 F-H, 3-5)$ : Carapace elongate with convex ventral and dorsal margins and welldeveloped projecting caudal process with rounded posterior margin (Figures $2 F, 3 A$, $5 E)$. Anterodorsal corner of rostrum evenly rounded, inferior top of rostrum pointed, anterior margin of rostrum slightly concave, and anterior of valve with deep incisure (Figure $3 B, C)$. Outer surface of valve smooth, with 1 small anterior bristle dorsal to midheight of rostrum and longer bristle at inferior corner, 4 small bristles forming row ventral to inner edge of incisure and set back from anterior edge of valve, and small bristles along ventral edge of valve. Valve just ventral to incisure with 2 broad triangular outwardpointing processes with bases just inward from valve edge (Figure $5 F$ ) (not present on врвм-S 12258). Anteroventral edge of each valve with 5 to 9 bristles; edge of valves in vicinity of anterior bristle without minute nodes.

Infold: Narrow list with anterior end on anteroventral infold extends along ventral margin, then broadens to broad shelf at anterior end of caudal process. Rostral infold with 8 to 11 bristles, some divided, plus pair of bristles near inner end of incisure and small bristle posterior to pair of bristles (Figure $3 B, C$ ); about 25 small bristles along anteroventral and ventral lists. Posterior edge of ridge forming anterior of caudal process of right valve with 10 to 13 stout spines (Figure $3 E)$; posterior edge of ridge of left valve smooth (Figure $3 D$ ). Pocket or right valve with 2 stout bristles beneath broad anterior ridge (Figure $3 E$ ). Minute spines or pores observed in pockets of some specimens.

Selvage: Lamellar prolongation with smooth outer edge present along anterior and ventral margins, terminating posteriorly near ventral end of caudal process. Prolongation widest and with narrow striations in vicinity of incisure (Figure $5 F$ ) and divides at inner edge of incisure. 


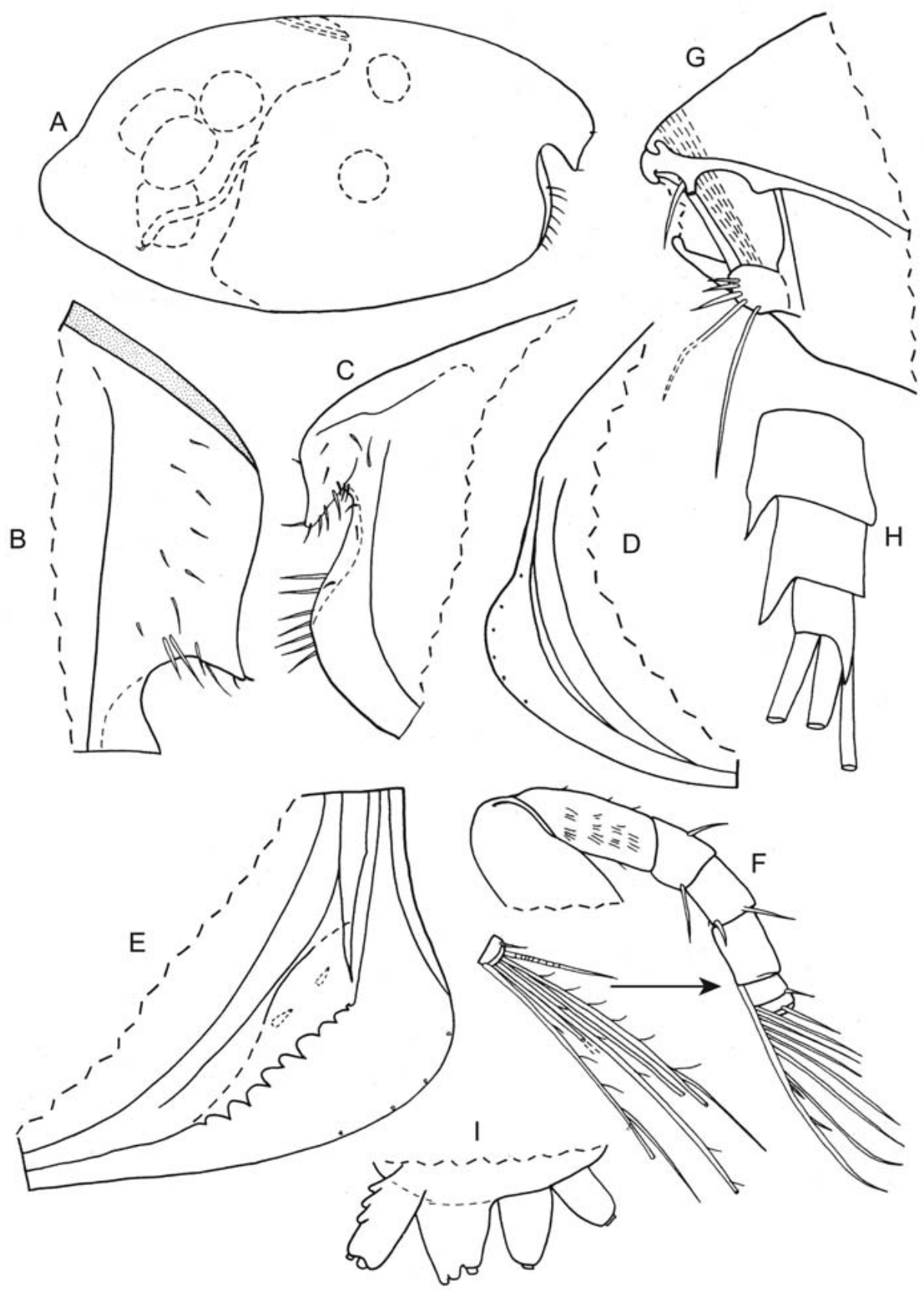

Figure 3. Cypridina mellentini, n. sp., ovigerous female, holotype, врвм-S 12258: $A$, complete specimen from right side showing dashed outlines of right lateral eye, central adductor muscles, right 7 th limb, 4 eggs in marsupium, and posterior edge of body; length $1.16 \mathrm{~mm} B$, , rostrum of left valve, inside view; $C$, anterior of right valve, inside view; $D$, posterior of left valve, inside view; $E$, caudal process of right valve, inside view; $F$, left 1 st antenna, medial view; $G$, protopod and endopod of right 2 nd antenna, medial view; $H$, articles 7-9 of left 2 nd antenna, lateral view; $I$, upper lip from right side, anterior to right. 
Central adductor muscle attachments (Figure $2 G$ ): Consisting of about 15 round and elliptical scars.

Carapace size (length, height in $\mathrm{mm}$ ): врвм-S 12256, 1.16, 0.64; вРвм-S 12258, $1.19,0.66$; врвм-S 12259, 1.14, 0.75; USNм $1075533,1.19,0.72$; врвм-S 12257, 1.25 , 0.66 . врвм-S 12262 (3 specimens): 1.25 , $0.68 ; 1.21,0.72 ; 1.22,0.72$. врвм-S 12264 , $1.19,0.64$. Average length $1.20 \mathrm{~mm}$.

First antenna (Figure $3 F$ ): 1st article bare. 2nd article with many medial spines and few ventral and dorsal spines. 3rd article short, with 2 short bristles (1 ventral, 1 dorsal). 4th article with 2 short, bare terminal bristles (1 ventral, 1 dorsal). Sensory bristle of short 5 th article with 6 long filaments followed by 2 short filaments (proximal of these close to base of distal long filament). 6th article with short, bare medial bristle. 7th article: a-bristle bare, slightly longer than bristle of 6th article; b-bristle shorter than c- and d-bristles, bare with proximal rings; c-bristle long with many filaments. 8th article: $\mathrm{d}$ - and e-bristles bare; f- and g-bristles long with many filaments; g-bristle longer than f-bristle.

Second antenna: Protopod with small medial bristle (Figure 3G). Endopod with single article with 5 bristles (1 long filamentlike, 1 medium ringed, 3 short ringed) (Figure $3 G$ ). Exopod: medial side of article 1 terminates in spinelike triangle near midwidth; dorsal margin with few spines; 2nd article with bristle (reaching 7th article) with 2 proximal hairlike ventral spines followed by 7 stout spines (last spine longer); articles 3 to 8 with long bristles with natatory hairs, but no spines; 9th article with 3 bristles: short dorsal bristle bare, 2 long bristles with natatory hairs but no spines. Articles 3 to 8 with slender basal spines longer on distal articles (Figure $3 H$ ). Article 9 with lateral spine. No minute spines forming row along distal margins of any articles of exopod.

Mandible (Figure 4A): Coxa: endite spinous with 2 stout terminal spines with smaller triangular process between them; small bristle at base of endite. Basis: dorsal margin with few proximal spines and 3 bristles (1 distal to midlength, 2 subterminal); proximal ventral corner with 2 small medial a-bristles; ventral margin with 1 small b-bristle, 1 minute cbristle, 1 long c-bristle, and 2 d-bristles. Exopod about same length as dorsal margin of 1st endopod article, with 2 subterminal bristles (distal shorter), and hirsute tip. Endopod: 1st article with 4 ventral bristles (1 long, 2 short, 1 minute). 2nd article: ventral margin with spines and 4 short bristles ( 2 single, 2 terminal paired); dorsal margin with few proximal spines, 5 short spinous bristles, 2 medium bristles, and 4 long bristles. 3rd article with 3 claws of equal length and 4 ringed bristles (2 short medial near ventral margin, 1 short lateral near dorsal margin, 1 long terminal near ventral margin).

Maxilla (Figure $4 B-D$ ): Endite I with 6 bristles and claws, endite II with 5 bristles (some bristles missing on illustrated limbs [Figure $4 B, C$ ]), and endite III with 5 or 6 bristles. Coxa with spinous dorsal bristle. Basis with 1 or 2 short ventral bristles and dorsal hairs. Endopod: 1st article with dorsal hairs, 1 alpha-bristle, 2 beta-bristles, and 2-pronged cutting tooth (right limb of врвм-S 12256 with thumblike cutting tooth). 2nd article with 3 lateral a-bristles, 2 b-bristles, 2 cbristles, and 3 d-bristles.

Fifth limb (Figures 4E,F, 5I,7): Epipod with 34 plumose bristles. Coxa: endite I with 4 or 5 bristles (Figure $5 I$ ), endite II with 4 bristles and 1 small triangular process, endite III with 5 or 6 bristles and triangular process. Basis: endite I (main tooth) with 6 stout pectinate teeth, small proximal triangular peg, and spinous bristle proximal to peg (Figure $4 F$ ), 2 bristles proximal to largest tooth (Figure 5I); endite II with 7 a- and b-bristles, 1 long spinous c-bristle, and 1 long spinous dbristle. Endopod: 1st article with 1 proximal and 2 terminal bristles (shorter terminal bristle without rings); fused articles 2 and 3 with 2 terminal bristles.

Sixth limb (Figure 4G): Epipod with 3 short bristles. Endite I with 1 long and 2 short bristles, endite II with 1 long and 2 short bristles, endite III with 2 long and 1 short bristles, endite IV with 1 long and 1 short bristles. End article spinous and with 5 short and 2 long bristles.

Seventh limb (Figure 5A): 2 short bristles ( 1 on each side), each with 3 bells; edge of 


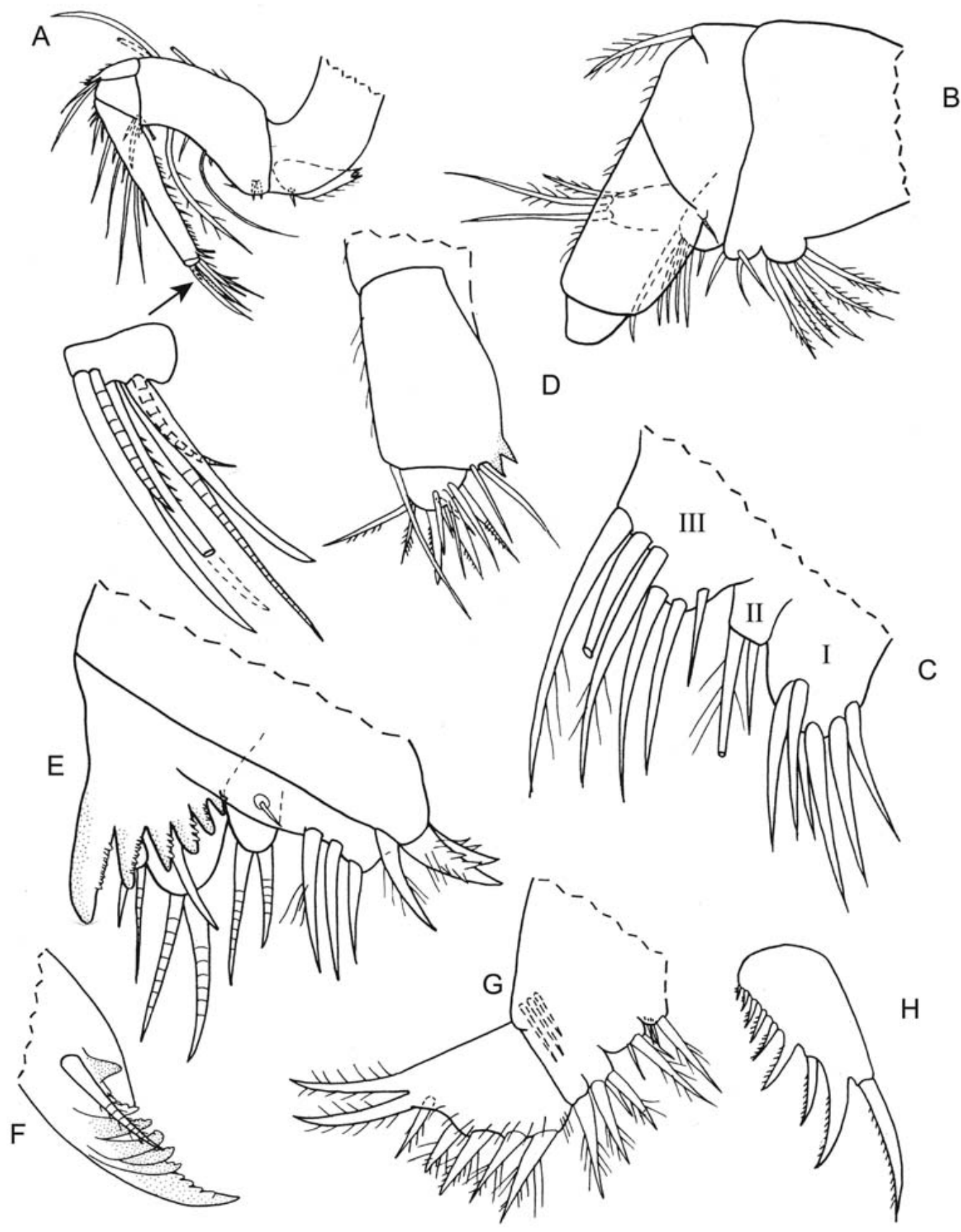

Figure 4. Cypridina mellentini, n. sp., ovigerous female, holotype, врвм-S 12258: $A$, left mandible, lateral view; $B$, right maxilla (nabs), medial view; $C$, endites I-III left maxilla, lateral view; $D$, endopod left maxilla, lateral view; $E$, distal left 5th limb (not all bristles shown), medial view; $F$, main tooth right 5 th limb; $G$, right 6 th limb, lateral view; $H$, left furcal lamella, medial view. 


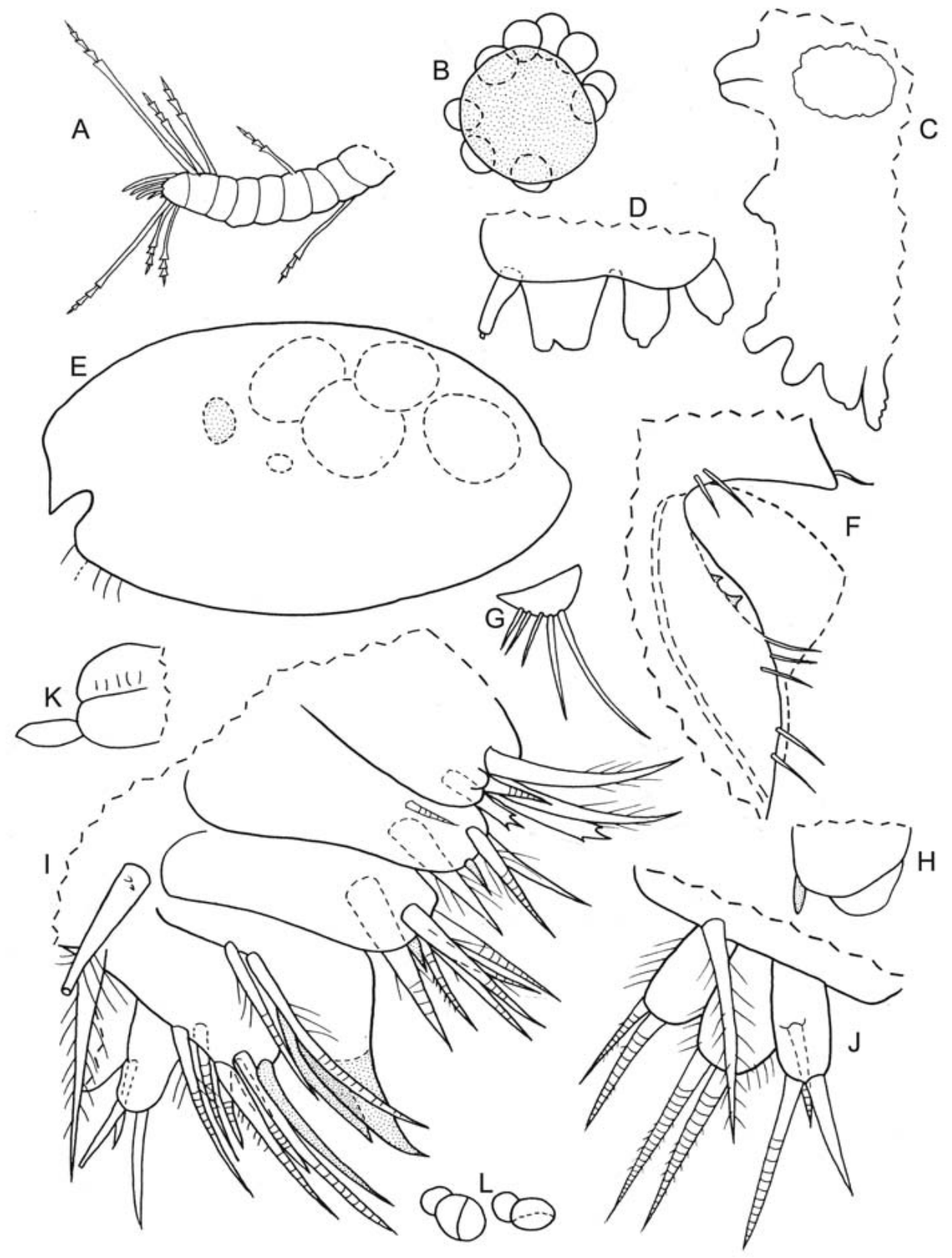

Figure 5. Cypridina mellentini, n. sp., ovigerous female: $A-D$, holotype, врвм-S 12258: $A$, 7th limb; $B$, right lateral eye; $C$, anterior of body from left side, anterior to left (Bellonci Organ not shown); $D$, lower lip from right side (posterior 2 lobes are left pair), anterior to right. $E-L$, paratype, врвм-S 12256: $E$, complete specimen from left side showing left lateral eye, outlines of central adductor muscle attachment, and 4 eggs in marsupium, length $1.16 \mathrm{~mm} ; F$, anterior left valve, inside view; $G$, endopodite of right 2 nd antenna, medial view; $H$, tip of right maxilla (not all bristles shown), lateral view; $I, \mathcal{F}$, part left 5 th limb (not all bristles shown), lateral view; $K$, medial eye and Bellonci Organ from left side; $L$, right and left genitalia. 
terminal segment with 6 bristles ( 2 short bristles on each side with 3 bells, 1 long bristle on each side with 4 bells). Comb with total of 7 teeth (middle tooth long, 2 on each side slightly shorter, 1 on each end short; walls of bristles of same thickness along length of bristles). Minute triangular process opposite comb (process difficult to resolve with certainty).

Furca (Figure 4H): Each lamella with 9 claws with teeth along posterior edges; claws 2 and 4 nonarticulated; claw 3 narrower than claw 4 but about same length; right lamella anterior to left by width of base of claw 1 . Furca missing on врвм-S 12256.

Bellonci Organ (Figure $5 K$ ): Short with triangular tip.

Eyes: Medial eye bare with light amber coloration along midline (Figure $5 C, K)$. Lateral eye larger than medial eye, with dense black pigment and about 17 light ambercolored ommatidia, some with bisecting suture (Figures $2 F, 3 A, 5 B, C, E$ ).

Upper lip (Figures 2H, 3I): With 2 unpaired anterior processes and 2 paired posterior processes; posterior of paired processes about same length or longer than anterior of paired processes. Left posterior process of paired processes of врвм-S 12258 aberrant in being very narrow (Figure $5 D$ ).

Anterior of body: Small process ventral to base of 1st antenna.

Posterior of body: Evenly rounded, bare.

Y-Sclerite: Typical for subfamily.

Genitalia (Figure 5L): Comprising 2 ovoid processes, each with attached spermatophore.

Brushlike bristles: Not observed.

Eggs (Figures $2 F, 3 A, 5 E$ ): врвм-S 12258 with 4 eggs in marsupium and with unextruded eggs of two sizes; diameter of one extruded egg $0.15 \mathrm{~mm}$. Many specimens with 9 or 10 eggs in marsupium.

Gut content: Unidentified fine-grained particles.

Parasites: врвм-S 12256 with copepod parasites at several stages of development and 9 parasite egg clusters in marsupium. USNM 1075533 with large unextruded eggs containing many fairly large spheres resembling parasite egg clusters.

Description of A-1 male: Carapace similar in shape to that of adult male. Anterior ridge of caudal process of right valve with spines; left valve without spines. врвм-S 12261 with 5 or 6 bristles along anteroventral edge of valve. врвм-S 12261 with appendages of adult male visible within appendages.

Carapace size (length, height in $\mathrm{mm}$ ): врвм-S 12261, 1.04, 0.58 .

Appendages: Not examined in detail, but viewed through valve of врвм-S 12261, appendages similar in gross morphology to those of adult female.

Furca: Each lamella with 8 claws; claws 2 and 4 nonarticulated.

Upper lip: Similar to that of adult female.

Copulatory organ: With 2 lobes (observed through valve on врвм-S 12261).

Composition of population: One specimen in the collection is an A-1 male. The 17 additional specimens are adult females, of which nine $(53 \%)$ have eggs (eight specimens) or embryos (one specimen) in their marsupia. One nonovigerous adult female has copepod parasites and egg clusters in the marsupium.

comparisons: Two species of Cypridina have been reported previously from Samoa by Poulsen (1962:262, 264): C. sinuosa (Müller, 1906) and $C$. inermis (Müller, 1906). The female furca of $C$. inermis and $C$. nana Poulsen, 1962, differs from that of the female of the new species $C$. mellentini in having the 4th claw articulated. The carapace of $C$. mellentini is smaller than that of $C$. sinuosa, and the middle tooth of the comb of the 7 th limb of $C$. sinuosa is much longer than that of C. mellentini.

\section{Family Cylindroleberididae Müller, 1906}

The Cylindroleberididae includes three subfamilies: Cylindroleberidinae, Asteropteroninae, and Cyclasteropinae. Only the Asteropteroninae have a representative in the collection reported here.

Subfamily Asteropteroninae Kornicker, 1981

Only the genus Asteropterygion is represented in this collection. 
Genus Asteropterygion Kornicker, 1981

TYPE SPECIES: Asteropterygion thomassini Kornicker, 1981.

composition and Distribution: The genus contains many species and is cosmopolitan between about $34^{\circ} \mathrm{N}$ and $41^{\circ} \mathrm{S}$, mainly at shelf depths. Members of the genus have not previously been reported from central $\mathrm{Pa}-$ cific islands.

Asteropterygion thomassini Group (Kornicker,

This informal group contains members having a clawlike a-bristle (generally with a rounded tip) on the 7 th article of the 1 st antenna.
Asteropterygion samoa Kornicker \& HarrisonNelson, n. sp.

Figures 6-9

HOLOTYPE: врвм-S 12254, juvenile female (instar ?TV) on slide and in alcohol. Unique specimen.

TyPe locality: Station 2, Fagatele Bay, Tutuila, American Samoa, 14 October 2002. paratypes: None.

Distribution: Type locality.

DESCRIPTION OF JUVENILE FEMALE (Figures 6-9): Oval in lateral view with incisure forming right angle (Figures 6, 7 $A$ ); posterior margin evenly rounded; posterodorsal area with 2 or 3 low ridges (Figures $6,7 B$ ).

Ornamentation (Figure 6): Surface with abundant round fossae and pustules.

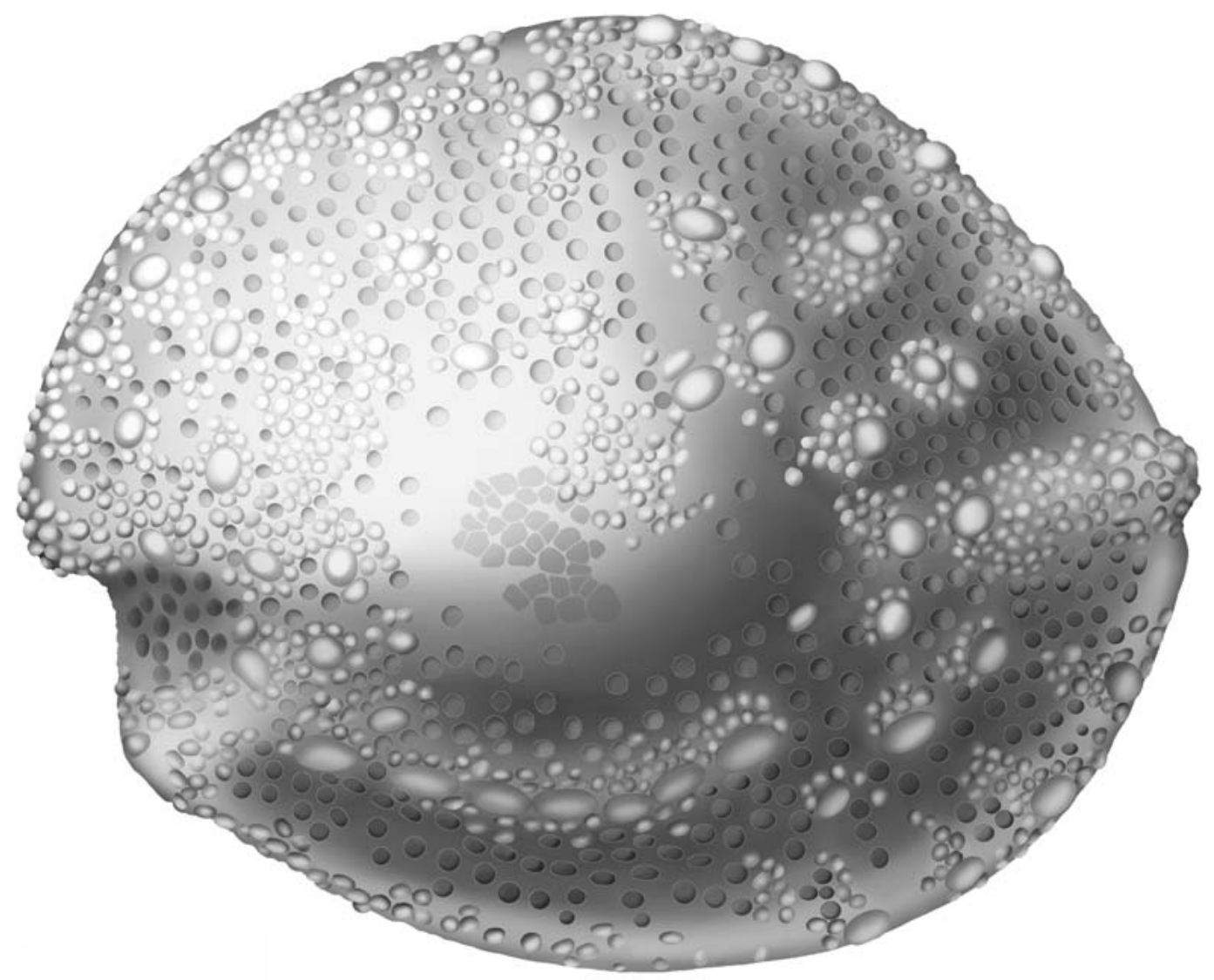

Figure 6. Asteropterygion samoa, n. sp., juvenile female (instar ?IV), holotype, врвм-S 12254, outside view of right valve, length $1.69 \mathrm{~mm}$. 
Central muscle attachment scars (Figure $7 C)$ : Numerous ovoid attachments.

Hinge teeth: Socket absent on right valve.

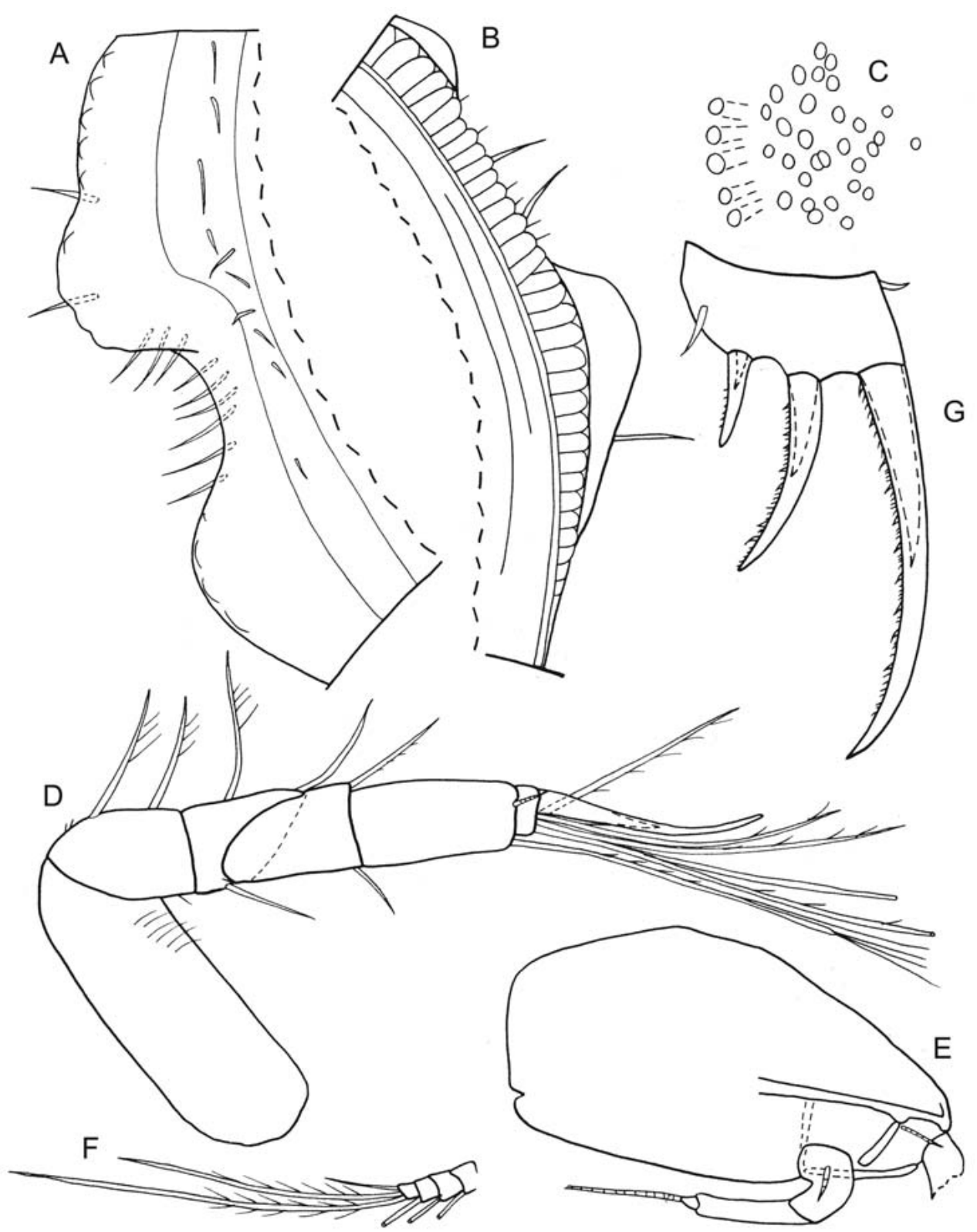

FIGURe 7. Asteropterygion samoa, n. sp., juvenile female (instar ?IV), holotype, врвм-S 12254: $A$, anterior of right valve, inside view; $B$, posterior of right valve, inside view; $C$, central adductor muscles protruding from left side of body; $D$, left 1st antenna, medial view; $E$, protopod and endopod of left 2 nd antenna, medial view; $F$, articles 6-9 of exopod of right 2nd antenna, lateral view; $G$, right furcal lamella (claws of next instar dashed), lateral view. 
combined lengths of articles 3 and 4, with dorsal and ventral spines and 2 spinous dorsal bristles. 3rd article with 2 dorsal bristles (1 at midlength, 1 terminal) and 1 terminal ventral bristle. 4th article with 2 terminal bristles (1 ventral, 1 dorsal). Sensory bristle of long 5 th article with 3 short proximal filaments and 4 long terminal filaments including stem. 6th article minute, fused to 5 th article, with minute medial bristle. 7 th article: a-bristle clawlike with rounded tip, about same length as articles 3 to 7 (measured along dorsal margin); b-bristle with 3 short marginal filaments; c-bristle long, with about 5 short marginal filaments. 8th article: d-bristle shorter than a-bristle of 7 th article, bare with blunt tip; e-bristle slightly shorter than sensory bristle of 5 th article, bare with blunt tip; f-bristle bent dorsally, about same length as b-bristle, with 5 short marginal filaments; g-bristle long, with 5 short marginal filaments.

Second antenna (Figure 7E,F): Protopod with short-ringed medial bristle. Endopod: article 1 short, with 1 short medial bristle; 2nd article elongate, bare; 3rd article short, with long terminal bristle with blunt tip. Exopod: 1 st article with minute terminal medial bristle; bristles of articles 2 to 8 with natatory hairs, no spines; 9th article with 3 bristles (1 dorsal, short, bare; 2 long with natatory hairs) (Figure $7 F$ ); all articles without basal spines.

Mandible (Figure $8 A-C$ ): Coxa endite of right limb without bristle near base of ventral branch (Figure $8 B$ ) (distal part of coxa endite of right limb and coxa endite of left limb lost). Basis: endite with 5 spinous end bristles at tip, 2 spinous end-type bristles and 1 triaenid bristle on ventral margin (triaenid bristle with 1 pair of spines much longer than others), and 2 medial dwarf bristles (Figure $8 C$ ); ventral margin of basis with 1 triaenid and 2 longer spinous bristles; dorsal margin with 1 short proximal bristle and 1 short and 2 long spinous terminal bristles. Exopod same length as dorsal margin of basis, hirsute distally and with 2 long subterminal bristles (distal bristle shorter and with marginal spines). Endopod: 1st article with 4 spinous ventral bristles (marginal spines dense on 2 shorter bristles). 2nd article: ventral margin with 3 long bristles (spines dense on shortest bristle); dorsal margin with about 11 bristles (2 clawlike with stout distal teeth); medial surface spinous. 3rd article with 3 stout claws and 2 slender bristles (ventral of these short).

Maxilla (Figure 8D): Epipod long, tapering to point, hirsute at tip. Endite I not clearly separated from endite II; endite I with 4 bristles ( 3 long, 1 short); endite II with 4 bristles (3 long, 1 short). Basis: dorsal margin with 1 short proximal bristle and 3 short distal bristles (1 longer than others); ventral margin with 1 short distal bristle and 1 long spinous terminal bristle; medial side with 1 short bristle near distal edge. Endopod: 1st article with 2 short anterior bristles and 1 long spinous beta-bristle; 2 nd article with 5 bristles. Exopod with 2 short bristles without lobe.

Fifth limb (Figure 9A): Comb with ventral bristles and distal dorsal hairs. Lateral side with long spinous exopod bristle and several smaller bristles near ventral margin.

Sixth limb (Figure 9B): Right limb: anterior margin with only lower suture well developed; medial side near anterior margin with 4 long and 4 short bristles; anterior proximal corner with small medial bristle with terminal spine. Anteroventral corner in vicinity of lateral flap with 5 spinous bristles; ventral margin posterior to flap with $10 \mathrm{spi}$ nous bristles; medial surface near ventral margin with 7 small bristles; posteroventral corner with hirsute projection. Limb with abundant spines and hairs. Left limb: anterior margin with only lower suture well developed; medial side near anterior margin with 3 long and 4 short bristles; anterior proximal corner with small medial bristle with terminal spine. Anteroventral corner in vicinity of lateral flap with 7 spinous bristles; ventral margin posterior to flap with 8 long bristles; medial surface near ventral margin with 9 short bristles; posteroventral corner with hirsute projection. Limb with abundant spines and hairs. Right limb with total of 31 bristles, left limb with 32. Lateral anterior flap of both limbs with long hairs but no bristles.

Seventh limb (Figure 9C): Right limb with 23 tapered bristles (13 on one side, 10 on other), each bristle with 2 to 5 bells. Some rings with bristle on each side. Terminus 


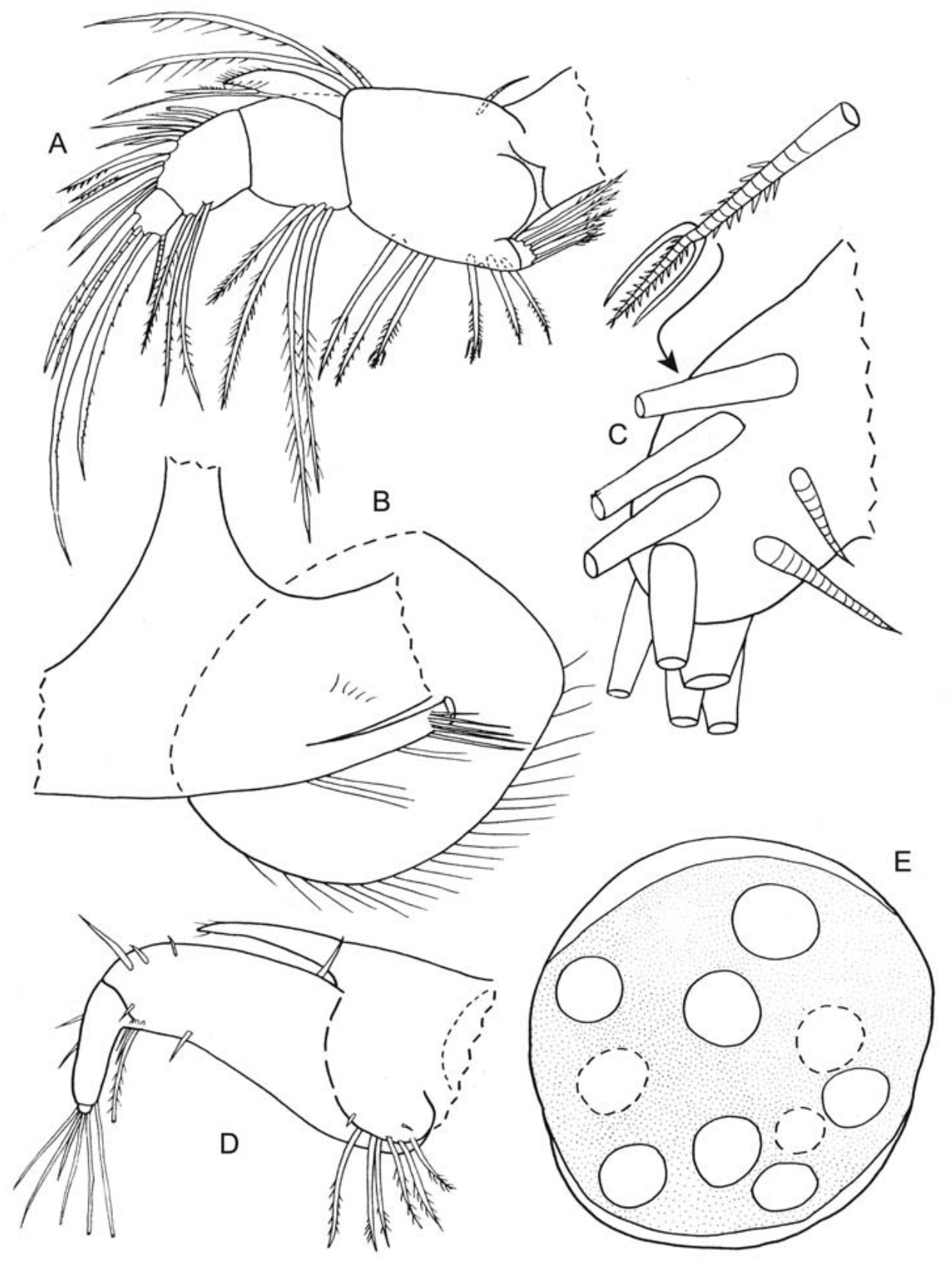

Figure 8. Asteropterygion samoa, n. sp., juvenile female (instar ?IV), holotype, врвм-S 12254: $A$, left mandible (coxa endite not shown), lateral view; $B$, proximal part of coxa endite of right mandible and right lower lip, medial view; $C$, basis endite right mandible, medial view; $D$, right maxilla (not all bristles shown), medial view; $E$, lateral eye. 


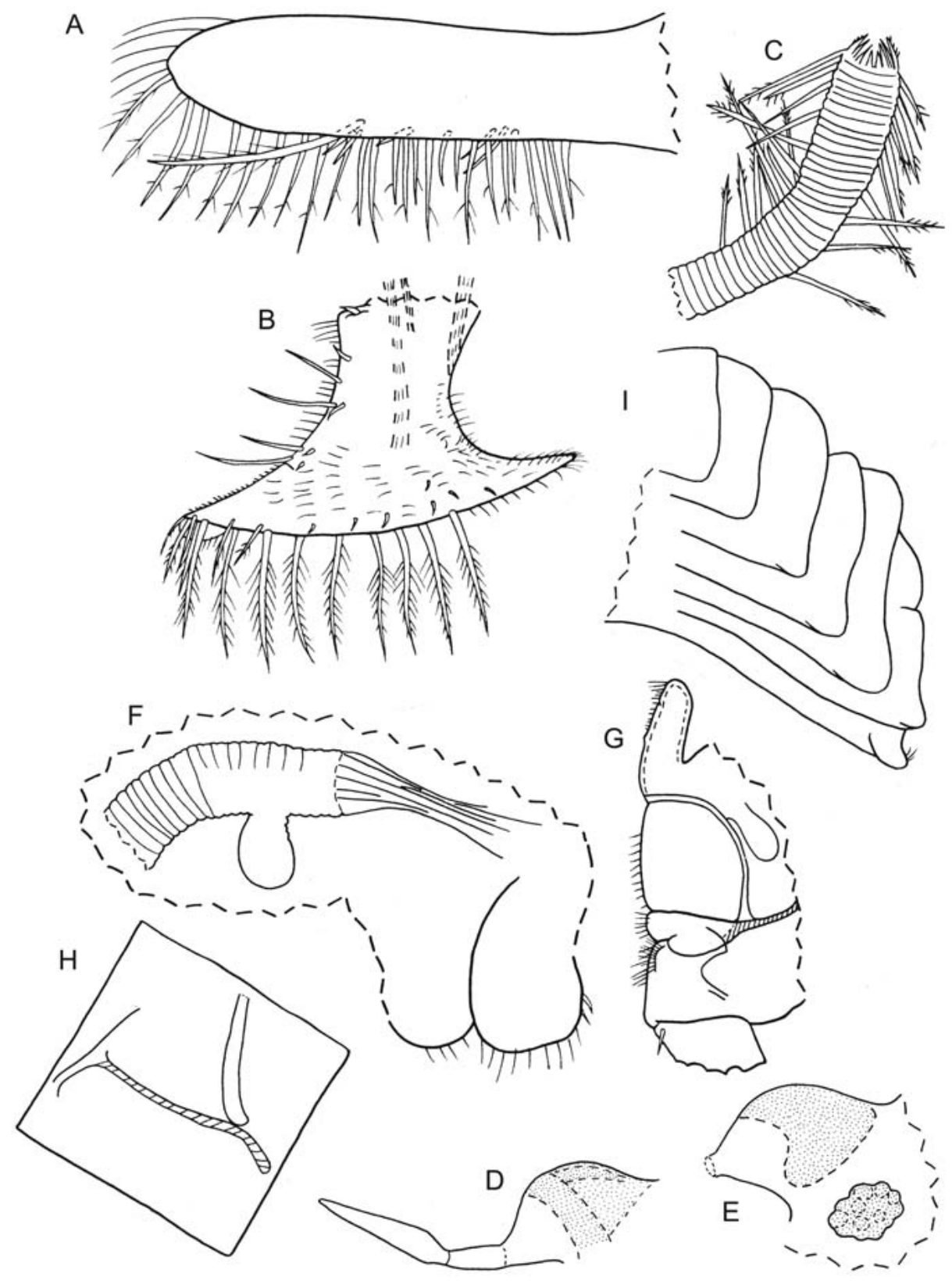

Figure 9. Asteropterygion samoa, n. sp., juvenile female (instar ?IV), holotype, врвм-S 12254: $A$, comb of right 5th limb, medial view; $B$, right 6th limb, medial view; $C$, 7th limb; $D$, medial eye and Bellonci Organ from left side; $E$, medial eye and lateral eye from left side; $F$, upper lip and anterior end of esophagus from right side, anterior to right; $G$, posterior of body from right side, anterior to right; $H$, left Y-sclerite (striated), anterior to left; $I$, posterior ends of gills on left side of body. 
with opposing combs, each with about 6 spinous teeth. Bristles of next instar visible inside bristles.

Furca (Figure 7G): Each lamella with 3 long, stout claws followed by 1 short, slender secondary claw. Right lamella anterior to left by width of claw 1 at base.

Bellonci Organ (Figure 9D): Broad near midlength, then tapering to rounded tip.

Eyes: Medial eye large, with dark brown pigment, bare (Figure 9D,E). Lateral eye smaller than medial eye, with dark pigment and about 10 ommatidia (Figures $8 E, 9 E$ ).

Lips (Figure 9F): Not clearly observed. Esophagus near mouth may have small pocket (Figure $9 F$ ).

Posterior of body (Figure 9G): Posterior hirsute, with fingerlike dorsal process with spines at tip. About 7 well-developed gills on each side (Figure 9I).

Y-Sclerite (Figure 9H): Unbranched, typical for genus.

COMPARISONS: The unique specimen in the collection is a late-instar female, at least an instar IV because of the 7th limb having numerous bristles. Many species of Asteropterygion have been based on juveniles (e.g., Poulsen 1965:216). Species of the genus have not previously been reported from a central Pacific island. The new species differs from A. magnum Poulsen, 1965, reported from off Australia, in having lateral eyes. The dorsal margin of the basis of the maxilla of $A$. samoa differs from that of other species in having relatively short distal bristles; other species have one or more very long bristles. The presence of only one secondary claw on each lamella of the furca of the unique specimen indicates that the adult furca will have few secondary claws. The 2 nd article of the 1 st antenna of the unique specimen is unusually short for members of the genus.

\section{ACKNOWLEDGMENTS}

We are grateful to S. L. Coles, Bernice P. Bishop Museum, Honolulu, Hawai'i, for sending us the specimens and for critiquing the manuscript. Collections were made by P. Reath and V. Bonito, also of the Bernice P. Bishop Museum. We thank Molly Ryan,
Smithsonian Institution, for rendering the carapace of Asteropterygion samoa and preparing the map in Figure 1; Megan Bluhm for inking the camera-lucida illustrations of the carapaces and appendages; and Jessica Rawlins for scanning and lettering the figures.

\section{Literature Cited}

Baird, W. 1850. The natural history of the British Entomostraca. London. [Printed for the Ray Society.]

Brady, G. S. 1898. On new or imperfectly known species of Ostracoda, chiefly from New Zealand. Trans. Zool. Soc. Lond. 14:429-452.

Cohen, A. C., and L. S. Kornicker. 1975. Taxonomic indexes to Ostracoda (Suborder Myodocopina) in Skogsberg (1920) and Poulsen $(1962,1965)$. Smithson. Contrib. Zool. 204.

Coles, S. L., P. R. Reathe, P. A. Skelton, V. Bonito, R. C. DeFelice, and L. Basch. 2003. Introduced marine species in Pago Pago Harbor, Fagatele Bay and the National Park Coast, American Samoa. Bishop Mus. Tech. Rep. 26.

Hartmann, G., and H. S. Puri. 1974. Summary of neontological and paleontological classification of Ostracoda. Mitt. Hamb. Zool. Mus. Inst. 70:7-73.

Kornicker, L. S. 1970. Ostracoda (Myodocopina) from the Peru-Chile Trench and the Antarctic Ocean. Smithson. Contrib. Zool. 32.

. 1981. Revision, distribution, ecology, and ontogeny of the ostracode subfamily Cyclasteropinae (Myodocopina: Cylindroleberididae). Smithson. Contrib. Zool. 319:1-548.

- 1987a. Ostracoda (Myodocopina) of Enewetak Atoll. Chapter 21, Pages 217219 in D. M. Delaney, E. S. Reese, B. L. Burch, and P. Halftrack, eds. The natural history of Enewetak Atoll. Vol. 2. Biogeography and systematics. U.S. Department of Energy, Office of Scientific and Technical Information, Oak Ridge, Tennessee. . 1987b. Supplementary description of Cypridina americana (Müller, 1890), a luminescent myodocopid ostracode from the 
East Pacific. Proc. Biol. Soc. Wash. 100 (1): $173-181$.

. 1991. Myodocopid Ostracoda of Enewetak and Bikini Atolls. Smithson. Contrib. Zool. 505:1-140.

1992. Myodocopid Ostracoda of the

Benthedi Expedition, 1977, to the NE Mozambique Channel, Indian Ocean. Smithson. Contrib. Zool. 531.

Milne-Edwards, M. 1840. Ordre des Cyproides ou des Ostracodes. Histoire $\mathrm{Na}$ turelle des Crustaçes 3:393-411. Librairie encyclopédique de Roret, Paris, France.

Müller, G. W. 1890. Neue Cypridiniden. Zool. Jahrb. 5:211-252.

1906. Ostracoda. In Max Weber, ed. Siboga Expeditie, Uitkomsten op Zoologisch, Botanisch, Oceanographisch en Geologisch Gebied Verzameld in Nederlandsch Oost-Indie 1899-1900 aan Boord H. M. Siboga ..., Monographien 30:140. E. J. Brill, Leiden, Holland.

. 1912. Crustacea: Ostracoda. Das Tierreich 31:1-434.

Poulsen, E. 1962. Ostracoda-Myodocopa, 1: Cypridiniformes-Cypridinidae. Dana Rep. Carlsberg Found. 57:1-414.

1965. Ostracoda-Myodocopa, 2: Cypridiniformes-Rutidermatidae, Sarsiellidae and Asteropidae. Dana Rep. Carlsberg Found. 65:1-484.

Sars, G. O. 1865 [1866]. Oversigt af Norge marine Ostracoder. Forhandlinger I Vidensk.-Selskabet I Christiania 8:1-130.

Skogsberg, T. 1920. Studies on marine Ostracods I: Cypridinids, halocyprids, and polycopids. Zool. Bidr. Upps., supplement 1:1-784.

\section{Appendix}

Station Locations and Descriptions and Number of Specimens of Each Species of Myodocopa Collected in the Vicinity of Tutuila, American Samoa (Station Data from S. L. Coles, Bishop Museum [in lit. 29 May 2003])

Station 2, Fagatele Bay, 14 October 2002, 14 21.96' S, $170^{\circ} 45.85^{\prime} \mathrm{W}, 21-24 \mathrm{~m}$. Site is a rich coral area with high relief and channels littered with coral rubble and coarse sand. Coral is very abundant on ridges between channels and dominated by Pocillopora, Acropora, and Montipora species with cover up to $>60 \%$ in high-abundance areas. Most of the rubble in the narrow channels is cemented together by sponges and calcareous algae and much was being covered by a surface of encrusting corals (mainly Montipora spp.). Below $15 \mathrm{~m}$, the reef sloped more steeply into a zone of predominately small/mediumsized coral rubble $(18-22 \mathrm{~m})$ and flattened out into a sandy bottom at $\sim 24 \mathrm{~m}$. High water clarity and visibility to $20 \mathrm{~m}$.

Asteropterygion samoa: 1 juvenile.

Station 4, Pago Pago Harbor, Main Dock, 15 October $2002,14^{\circ} 16.59^{\prime} \mathrm{S}, 170^{\circ} 41.26^{\prime} \mathrm{W},+0.5-8 \mathrm{~m}$. Pilings and bottom along main dock from east end and around corner to smaller dock and ending at rocky jetty and sheet piling near Department of Marine and Wildlife Resources offices. Depth ranged from 4 to $10 \mathrm{~m}$ with bottom of coarse sand with thin muddy surface and abundant trash and metal scrap that provide hard surfaces for settlement. Sampled from dock pilings, which support abundant fouling, including species recognized as nonindigenous in Hawai'i (i.e., Pennaria disticha, Schizoporella cf. errata, Amathia distans, and Mycale sp.?). Echinoderms Diadema setosum and Echinothrix diadema were abundant in shallow area along second dock, and oysters were abundant in shallow subtidal on sheet piling and rocky jetty. Water very turbid and visibility ca. $3-4 \mathrm{~m}$.

Paravargula trifax: 1 juvenile. Cypridina mellentini: 1 specimen.

Station 5, Pago Pago Harbor, Dry Dock, 15 October $2002,14^{\circ} 16.32^{\prime} \mathrm{S}, 170^{\circ} 41.54^{\prime} \mathrm{W}, 6-10 \mathrm{~m}$. Bottom is a steep slope covered by coarse muddy sand/silt along the edge of a seawall next to a dry dock west of the tuna canneries on north side of the harbor near its head. Bottom was totally barren of macrobiota except for intermittent trash consisting of old tires, ropes, fiberglass, and metal scrap, which provide surfaces for fouling of sponges, bryozoans, including nonindigenous Amatbia distans tunicates, and some algae. Visibility very low $(1-2 \mathrm{~m})$ in surface layer due to recent rainfall but increased to 5-6 m near bottom. Cypridina mellentini: 1 specimen.

Station 6, Pago Pago Harbor, Onososopo, 16 October $2002,14^{\circ} 17.18^{\prime} \mathrm{S}, 170^{\circ} 39.89^{\prime} \mathrm{W}, 1.5-24 \mathrm{~m}$. Narrow (ca. $150 \mathrm{~m}$ ) fringing reef with high coverage of Acropora and mixed coral species that drops steeply to a mixed sand/coral rubble bottom at ca. $25 \mathrm{~m}$. The reef flat consists of a shallow 1- to 2-m, sandy moat area with ca. $5-20 \%$ coral cover and few narrow, shallow grooves cut out of the moat area toward the reef front and toward a channel area. These grooves are lined with small to medium-sized rubble well encrusted with sponges and tunicates. Thickets of staghorn Acropora from 10 to $30 \mathrm{~m}$ wide and $20-30 \%$ cover occur at 1-2 $\mathrm{m}$ depth on the reef flat offshore. Approaching the outer fringing reef crest is a shallow zone of mixed rubble, some of which was heavily encrusted with calcareous algae and/or coral with $<20 \%$ cover. The reef crest is uneven and has numerous cracks and crevices. Acropora spp., Pocillopora spp., and Millepora (mainly $M$. platyphylla) dominated the reef crest, which had patchy coral cover ranging from 40 to $60 \%$. The outer reef ranged from a 
steeply sloping $\left(\sim 60^{\circ}\right)$ hard surface littered with small/medium rubble to a wall-like drop-off that had a few overhangs but mainly was riddled with cracks and crevices. Coral cover decreases substantially in abundance below the reef edge and is dominated by Diploastrea, Echinophyllia, Coscinaria, and the soft coral
Lobophytum. The hard wall/slope area ended between 6 and $12 \mathrm{~m}$ where a steep soft-bottom slope continues. This slope is covered in pebble/cobble rubble. Coral cover on the deeper slope was patchy and $<10 \%$.

Cypridina mellentini: 15 specimens. 
